\title{
CHARLES EDWARD IVES AMERYKAŃSKI ŚPIEW WOLNOŚCI
}

„I hear America singing - Słyszę śpiew Ameryki...” Tymi słowami Walt Whitman (1819-1892) otwiera jeden ze swych słynnych wierszy ${ }^{1}$. „Falujące wersety” jego poezji, jak pisano, wnosiły w przestrzeń poetycką „hymn Boskiej energii i ludzkich s w o b ó d", ucząc zarazem nowości i wolności świata. Przytaczam te poetyckie słowa, gdyż zasadnie można je powtórzyć w kontekście osobowości i muzyki Charlesa Edwarda Ivesa (1874-1954), amerykańskiego twórcy-wizjonera. Manifestowane przez niego w muzyce sensotwórcze wartości i transcendentalia stały się istotne także dla kompozytorów polskich drugiej połowy XX wieku. Odnosząc się do muzyki z przełomu lat 60. i 70., na pytanie: o co nam szło? Leszek Polony odpowiedział znacząco:

Mówiąc krótko i najbardziej lapidarnie: o odnalezienie zacierającego się, z a g u bi o n e go s e n s u muzyki [wyróżnienie - M. J.S.], aktywności twórczej i w ogóle egzystencji ludzkiej w świecie. O promyk nadziei w świecie chaotycznym, zdezintegrowanym i zagrożonym apokalipsą. O osobiste przyświadczenie oczywistym i nie nowym przecież wartościom. Pojmowaliśmy wszystkie te sprawy integralnie i bardzo serio. ${ }^{2}$

W odzyskaną przestrzeń aksjologiczną weszło pokolenie Stalowej Woli - „nowych humanistów” czy „nowych romantyków”: Eugeniusz Knapik (ur. 1951), Andrzej Krzanowski (1951-1990) i Aleksander Lasoń (ur. 1951). Powracali do tego, co - za Michaiłem Bachtinem i Rogerem Scrutonem - określam mianem p a m i ę c i e m o cj o n a l n e j; powracali poprzez recepcję poglądów właśnie Ivesa i jego koncepcji muzyki jako zbioru wartości. Autor niedokończonej symfonii Uni-

${ }^{1}$ Zob. W. Whitman, ...styszę śpiew Ameryki, wybrał i przełożył A. Szuba, Warszawa 1995.

${ }^{2}$ L. Polony, O co nam szło, [w:] Przemiany techniki dźwiękowej, stylu i estetyki w polskiej muzyce lat 70., red. L. Polony, Akademia Muzyczna w Krakowie, Sekcja Muzykologów Związku Kompozytorów Polskich, Kraków 1986, s. 73-74. 
verse wierzył, iż muzyka w procesie immanentnej ewolucji rozwinie „język o takim stopniu transcendencji, że jego wyżyny i głębie będą wspólnotą całej ludzkości”3.

\section{Muzyka jako wartość}

Charles E. Ives pragnął w muzyce i muzyką głosić wolność i prawdę. Sztuka, pisał, „przychodzi wprost $\mathrm{z}$ serca, $\mathrm{z}$ doświadczenia życia, $\mathrm{z}$ myślenia o życiu i jego pełnego przeżywania"4. Kwintesencję światopoglądu kompozytora przynoszą autorskie Eseje przed Sonata (II Sonata fortepianowa „Concord”), które odczytywać można w kategoriach jedynego w swoim rodzaju traktatu kompozytorskiego. Ives uważał, że muzyka jest wewnętrznie dialektycznym, zhierarchizowanym zbiorem wartości. Składają się nań dwa podzbiory: wyższy podzbiór wartości treści (substance) i niższy podzbiór wartości stylu czy formy (manner), sposobu wyrażania rzeczonych treści.

Treść jako składnik jakościowy ludzkiej sztuki wiąże się z zespołem przekonań zrodzonych ze świ d o mości du chowej [wyróżnienie - M.J.S.], wykarmionych świadomością moralną i w rezultacie swego rozwoju przedstawionych w dojrzałej formie w postaci wyobrażenia. Wyobrażenie z kolei poddane zostaje ocenie intuicji i przełożone na ekspresję przez „styl” - proces zawsze mniej ważny (...). ${ }^{5}$

- konstatuje amerykański kompozytor.

Według twórcy Central Park in the Dark największą chorobą, jakiej może ulec muzyka, staje się uprawianie wypracowanego stylu indywidualnego, replikowanego w kolejnych utworach. Taki „bezpieczny”, w znaczeniu: sprawdzony, zewnętrzny i skonwencjonalizowany styl zniewala bowiem twórczą wyobraźnię oraz skutecznie przeszkadza ujawnić się wewnętrznej substancji, zabijając prawdę o niej. „Dlaczego myśli muzycznej nie można przedstawić tak, jak się ona rodzi - nawet jeśli się zdarzy, że jest «bękartem slumsów» albo "córką biskupa»?”6 - Ives stawia problem otwarcie. Przywołuje także ważną myśl Ralpha Emersona, czołowej postaci amerykańskich transcendentalistów, swego duchowego przywódcy: „Czemu gadacie tak głośno, że nie słyszę, co mówicie?"7.

\footnotetext{
${ }^{3}$ Ch. Ives, Eseje przed Sonatą, przełożył Piotr Graff, „Res Facta” (1971) 5, s. 54.

${ }^{4}$ Ch. Ives, Eseje przed Sonata, dz. cyt.

${ }^{5}$ Ch. Ives, Eseje, dz. cyt., s. 82.

${ }^{6}$ Ch. Ives, Eseje, dz. cyt., s. 86.

${ }^{7}$ Ch. Ives, Eseje, dz. cyt., s. 83.
} 
Ivesowski dychotomiczny podział wartości - „fundamentalną dwoistość sztuki” - możemy w sposób metaforyczny odnieść do Emersonowskiego przeciwstawienia intuicji i intelektu, ducha i inteligencji.

Treść jako składnik jakościowy ludzkiej sztuki wiąże się z zespołem przekonań zrodzonych ze świadomości duchowej, wykarmionych świadomością moralną i w rezultacie swego rozwoju przedstawionych w dojrzałej formie w postaci wyobrażenia. Wyobrażenie z kolei poddane zostaje ocenie intuicji i przełożone na ekspresję przez „styl” - proces zawsze mniej ważny. ${ }^{8}$

Według Ivesa treść z natury rzeczy jest nieopisywalna i niedefiniowalna w określonych kategoriach - wyczuwa się ją jedynie intuitywnie. Jako wyższy podzbiór wartości skłania się ku optymizmowi, podczas gdy niższy od niej styl zdradza inklinacje ku pesymizmowi. „Treść wytwarza miłość” - pisze kompozytor, „styl wytwarza uprzedzenie" ". Budując autorski system wartości, Ives zasymilował wiele z kanonu myśli Emersona: oparcie człowieka i świata o rzeczywistość duchową, konieczność poszukiwania prawdy i ciągłej pracy ducha, moralną autonomię człowieka i wiarę, że najwyższe prawdy czy wartości dostępne są dla każdej jednostki. Przyrodzie, otaczającej człowieka, Emerson przypisywał znaczenie religijne. W niej szukał spokoju, powrotu do poczucia Boskiej harmonii. Powtarzał refrenicznie: „Czymże jest farma, jak nie milczącą Ewangelią?”10. Wpływ przyrody posiada w jego odczuciu charakter moralny: budzi nie tylko uczucie wzniosłości, adoracji, ale i świadomość praw, na których oparte jest nasze życie. Doktryna transcendentalizmu, podstawa myślenia Ivesa, miała w intencji Emersona przywracać człowiekowi ufność we własne siły, rehabilitować jednostkę ludzką, wyzwalając ją od wszelkiej zewnętrznej presji oraz stać się optymistycznym podłożem wiary w postęp, rozumianym jako nieograniczona możliwość indywidualnego doskonalenia. To, co tworzył, pisał i głosił, nie było filozofią, nie było wyznaniem wiary, nie było tworzywem poetyckim, nie było pracą badawczą: było jednak tym wszystkim równocześnie” - stwierdza Artur Górski. „Były to erupcje sił duchowych, przychodzących do głosu z niepodzielnej jedności psychicznej (...)”"11. Podstawę filozoficznych przekonań Emersona stanowił romantyczny idealizm oraz wyrosła na jego fundamencie mistyczna i panteistyczna wiara w duchową jedność świata. Według amerykańskiego myśliciela człowiek to strumień, którego źródło jest ukryte. Myśli przepływają przez naszą wolę, ale to nie ona jest ich przyczyną,

\footnotetext{
${ }^{8}$ Ch. Ives, Eseje, dz. cyt., s. 82.

${ }^{9}$ Ch. Ives, Eseje, dz. cyt., s. 83.

${ }^{10}$ R. W. Emerson, Szkice, Warszawa 1933, s. 35

11 A. Górski, Przedmowa, [w:] R. W. Emerson, Szkice, Warszawa 1933, s. 20.
} 
gdyż pochodzą one z obcej energii. Tą naturą wyższą, w której spoczywamy, staje się „Naddusza” (Oversoul), dzięki niej tworzymy jedność i całość.

Kompozytor przywiązany był do ideałów i kultury swego ojca - George’a, „muzycznego majstra od wszystkiego", stąd jego zwrócenie się w postawie i twórczości do myśli amerykańskich romantyków - transcendentalistów. Ives dobrze pamiętał ojcowskie kategoryczne zalecenie: „Nie zwracajcie uwagi na dźwięki, gdyż możecie przegapić muzykę. Nie uda wam się bohaterski wjazd do nieba na milutkich małych nutach"12. Przewodnim motywem twórczości autora Unanswered Question stała się idea wolności, związana z możliwością indywidualnego twórczego wyboru. „Ten wybór tłumaczy” - pisze Ives, „dlaczego [na przykład] Beethoven jest zawsze nowoczesny, a [Ryszard] Strauss zawsze średniowieczny - jakkolwiek by się starał zamaskować to nowymi sztuczkami” ${ }^{13}$. W aksjologii kompozytora Ludwig van Beethoven, podobnie jak Emerson, reprezentuje odwagę wiary w wolność samą w sobie - także odwagę bycia sobą. Wybór jest wolnością - podkreśla Ives. Zauważa też: „[Ryszard] Strauss pamięta, Beethoven marzy”"14. I to właśnie Beethovena uważał za kompozytora największego w całej historii muzyki, sytuując go po stronie charakteru, który jest siłą i emanacją ducha. Ducha niedającego się wcisnąć w ramy konwencji i założonych a priori modeli formalnych.

Niektórzy chwalą Czajkowskiego za niezrównaną (albo inne podobne słowo) jasność i spójność zamysłu w utworach orkiestrowych

- wyjaśnia Ives.

Naszym zdaniem jest tak pod warunkiem, że powtarzanie należy do istoty jasności i spójności. Wiemy, że masło robi się ze śmietany, ale jak długo można patrzeć na ubijanie masła! Jeśli natura nie zdradza entuzjazmu do wyjaśniania, to dlaczego Czajkowski musi? (...) wielki „rosyjski płaczek” mógł nas oszczędzić. ${ }^{15}$

Osłabienie w muzyce siły moralnej i żywotnej wyczuwa Ives u Wagnera, nigdy u Bacha czy Beethovena. Wagner wybrał bowiem w jego rozumieniu pierwiastek przedstawiający, nie zaś - jak uczynił to autor Sonaty patetycznej - samego ducha. Stanął zatem po stronie niższego z zespołów wartości - wartości stylu. „Treść łączy się z charakterem” - stwierdza kompozytor. „Styl nie ma z nim nic wspólnego. Treść melodii pochodzi z pobliża duszy, styl zaś pochodzi - Bóg wie skąd"16.

\footnotetext{
${ }^{12}$ Cyt. za: H. i S. Cowell, Ives, tłum. zbiorowe, Kraków 1982, s. 30.

${ }^{13}$ Ch. Ives, Eseje, dz. cyt., s. 86.

${ }^{14}$ Ch. Ives, Eseje, dz. cyt., s. 87.

${ }^{15}$ Ch. Ives, Eseje, dz. cyt., s. 93.

${ }^{16}$ Ch. Ives, Eseje, dz. cyt., s. 83.
} 
W aksjologii Ivesa to właśnie twórca Eroiki, podobnie jak Emerson, reprezentuje odwagę wiary w wolność samą w sobie także w odniesieniu do siebie samego.

Muzyka w ujęciu Ivesa utrwalała immanentny jej w y m i a r a k s jol o g i c z $\mathrm{n}$ y : wartości etyczne kompozytor stawiał ponad estetycznymi. „Jałową rzeczą jest dobieranie pewnego typu, aby reprezentował «całość»" - przekonywał, „chyba że zainteresowanie duchem owego typu zbiega się z zainteresowaniem duchem całości"17. Tworząc nową i wyrazistą duchowo muzykę amerykańską, stał Ives na straży postawy idealistycznej i etosu kompozytora.

\section{Ives z perspektywy intertekstualnej}

Żyjemy i percypujemy świat z perspektywy intertekstów i interlektury. Już Michaił Bachtin zauważył: „Moje słowo pozostaje w trwającym dalej d i a l o g u [wyróżnienie - M. J. S.], gdzie będzie usłyszane, otrzyma odpowiedź i przekształci swój sens"18. Autor pracy Problemy poetyki Dostojewskiego mocno podkreślał, iż

Nie istnieje wypowiedź izolowana. Zawsze zakłada ona wypowiedzi, które ją poprzedzają oraz te, które nastąpią po niej. Żadna nie jest ani pierwszą, ani ostatnią. Wypowiedź stanowi tylko ogniwo łańcucha i nie może być badana w oderwaniu od niego. Między wypowiedziami zawiązują się relacje, których nie da się określić ani mechanicznie, ani lingwistycznie. Nie mają one żadnych analogii. ${ }^{19}$

Istotny jest u Bachtina także wymiar aksjologiczny: żyć oznacza dla niego z a j mować postawę wartościującą - i to w każdym momencie życia. Polifoniczny splot różnych głosów i opowiadanie się po stronie wartości przynosi właśnie muzyka Charlesa Ivesa.

Jeśli szukać muzycznej wykładni poglądów kompozytora, wybór pada, oczywiście, na jego II Sonatę fortepianową Concord. Skompletowana w roku 1915, rewidowana przez autora w roku 1918, a opublikowana w roku 1920 (eseje do niej powstały w roku 1919), określana była w recepcji jako „impresjonistyczna symfonia na fortepian” (John Kirkpatrick), utwór „umoralniający” (Henry Bellamann) czy „największa muzyka skomponowana przez Amerykanina” (Lawrence Gilman). Pisano także, że lokalne czy parafialne Concord podniesione w niej zostało do rangi symbolu nie tylko ogólnonarodowego, ale i uniwersalnego. Zwracano uwagę na za-

${ }^{17}$ Ch. Ives, Eseje, dz. cyt., s. 83.

${ }^{18}$ M. Bachtin, [w:] Bachtin. Dialog - Język - Literatura, red. E. Czaplejewicz, E. Kasperski, Warszawa 1983. s. 20.

${ }^{19}$ M. Bachtin, Problemy poetyki Dostojewskiego, tłum. N. Modzelewska, Warszawa 1970, s. 481. 
leżność dramaturgii sonaty, wpisującej się w ogólny wzór gatunku, od intensywnej ekspresji i semantyki, związanej z cytowaną przez Ivesa muzyką. Na jej czoło wysuwa się Beethovenowski m o t y w lo s u, symbol ludzkiego przeznaczenia.

Na początku V Symfonii jest „wyrocznia”; w tych czterech nutach zawiera się jedno z największych posłań Beethovena. Chciałoby się umieścić jej przekład ponad bezlitosnym losem, który puka do drzwi, ponad wielkim ludzkim posłaniem przeznaczenia, by zespolić ją z duchowym posłaniem objawień Emersona, z „pospólnym sercem” Concord - to dusza ludzkości puka do drzwi boskich tajemnic, promienna w wierze, iż będzie jej otworzone - a ludzkie stanie się boskim. ${ }^{20}$

Kolejne części Sonaty ukazują oblicza czołowych przedstawicieli ruchu transcendentalnego w Nowej Anglii: Ralpha Waldo Emersona, Nathaniela Hawthorne’a, Amosa Bronsona i Louisę May Alcottów oraz Henry’ego Davida Thoreau. Ives starał się oddać w muzyce prawdę o ich osobowości, cechach charakteru i kierunkach postępowania. „(...) czy wszelka muzyka nie jest programowa?”21 - retorycznie pyta autor. „Czy tak zwana czysta muzyka nie jest w swojej istocie przedstawiająca?"22 - te słowa kompozytora potraktować można jako jego artystyczne wyznanie wiary w „treściwą” i „mowną” moc sztuki dźwięków. Skoncentruję się na częściach skrajnych Sonaty. Jej część główna, będącą przedstawieniem materiału dlań podstawowego, portretuje Emersona-wizjonera. Inicjalna faza - Slow$l y$ - przynosi dwa motywy znaczące. Z motywu pierwszego, obdarzonego przede wszystkim funkcją strukturalną, wygenerowany zostaje heterogeniczny przebieg muzyczny. Motyw drugi - pokazywany w różnych melorytmicznych wariantach i kontekstach fakturalno-harmonicznych - pełni głównie funkcję symboliczną.

W osnowę pierwszej części Sonaty wpisana została B e e th ov e now sk a i d e a di a lekt y ki. Muzyka ma zarazem postać dramaturgii celu: kompozytor sugeruje użycie w jej konkluzji także altówki - ,jeśli będzie pod ręką”. Treści muzyki nie można przecież ograniczać środkami wykonawczymi. „Instrument! - oto odwieczna trudność, oto ograniczenie muzyki” - konstatuje Ives. I prowokacyjnie dodaje: „Czy to wina kompozytora, że człowiek ma tylko dziesięć palców?” ${ }^{23}$ I finał Sonaty. „Jeśli nasza muzyka ma mieć jakiś program” - wyjaśnia Ives, „to niech śledzi jego [Thoreau] myśl jesiennego dnia babiego lata nad [stawem] Walden (...)"24. Postać Thoreau, autora zbioru osiemnastu esejów napisanych w trakcie samotnej

\footnotetext{
${ }^{20}$ Ch. Ives, Eseje, dz. cyt., s. 67.

${ }^{21}$ Ch. Ives, Eseje, dz. cyt., s. 52.

${ }^{22}$ Ch. Ives, Eseje, dz. cyt., s. 52.

${ }^{23}$ Ch. Ives, Eseje, dz. cyt., s. 86.

${ }^{24}$ Ch. Ives, Eseje, dz. cyt., s. 78.
} 
dwuletniej egzystencji - „ogołoconego bytowania” 25 - w okolicach Concord, ukazana jest przez pryzmat wizji poetyckiej i uduchowionej. I swoim niepraktycznym zwyczajem Ives sugeruje użycie w zakończeniu Sonaty - fletu, instrumentu, na którym grał piewca natury. W jego głosie usłyszeć można motyw losu. „Czy jest to transcendentalna melodia Concord?”26 - pyta kompozytor. „Idzie «przez miłe wzgórze sosen» i księżycowego światła do swego szałasu, «z dziwną wolnością w naturze, częścią jej samej»" "27.

Technika cytacji oraz wariowania zapożyczonych motywów i tematów stała się dla Ivesa kluczową strategią kompozytorską, jego autorską sygnaturą w muzyce. Skrajną postać otrzymała w części Comedy drugiej z cyklu IV Symfonii (1910-1916), w której kompozytor przywołał melodie z ponad pięćdziesięciu źródeł, ukazując je tak w projekcji horyzontalnej (zasada continuum), jak i wertykalnej (zasada stretty). Pisano o niej: „ogłuszająca, paraliżująca wieża Babel melodycznych klocków, wysokości, rytmów i barw"28. Muzyka jest tu z założenia wewnętrznie antynomiczna, przynosi jednoczesne dzianie się wielu muzycznych akcji - koegzystencję w wymiarze przestrzennym różnych warstw brzmieniowych. Mechanizm egzystowania cytowanych melodii w projekcji symultanicznej porównać można - w sferze technicznej- do st r u mi e n i a świ a d o mości Jamesa Joyce’a. Ciągła fluktuacja elementów wywiedzionych z różnych źródeł ma charakter analogiczny do funkcjonowania świadomości: świat tych melodii rozwija się w ciągłości stanów, które nawarstwiają się i do których stale odwołuje się pamięć i wyobraźnia kompozytora. Comedy zainspirowana została opowieścią Nathaniela Hawthorne’a Celestial Railroad („Niebiańska kolej”), w której wędrówka prostych pielgrzymów zderzona została $\mathrm{z}$ brawurową jazdą do nieba mechaniczną koleją. Stymulatorem przebiegu muzycznego stają się tu cząstki przywoływanych przez kompozytora amerykańskich hymnów i marszów, na czele z Jesus, Lover of My Soul oraz Country Band March, włączone w proces transformacji, a nawet odkształceń oryginału. Styl nie ma przecież twórczego znaczenia: istotna jest treść muzyki, jej wewnętrzna substancja.

\section{Obecność Ivesa w muzyce polskiej. Rekonesans}

Postawa i muzyka Ivesa, nacechowane aksjologicznie, w wyrazisty sposób zarezonowały u kompozytorów polskich. Studiując twórczość przedstawicieli poko-

\footnotetext{
${ }^{25}$ Zob. T. Sławek, Ujmować: Henry David Thoreau i wspólnota świata, Katowice 2009.

${ }^{26}$ Ch. Ives, Eseje, dz. cyt., s. 79.

${ }^{27}$ H. D. Thoreau, Solitute. Walden (s. 143), cyt. za: Ch. Ives, Eseje, dz. cyt., s. 79.

${ }^{28}$ K. Stone, Ives's „Fourth Symphony: A Review, „The Musical Quarterly” (1966) 52, s. 7, tłum. MJS.
} 
lenia Stalowej Woli, Kinga Kiwała zauważa: „Ivesowski transcendentalizm w zaskakujący sposób współgrał z wartościami kultywowanymi na Śląsku - zwłaszcza z kultem pracy w obliczu i dla wartości najwyższych" ${ }^{29}$. Warto zaznaczyć, że utwory amerykańskiego twórcy uosabiały nie tylko e t o s woln o ści o w y, były także wyrazem komponowania dźwiękami złożoności życia.

Oto dwa znaczące przykłady:

- Stanisław Krupowicz (ur. 1952, reprezentujący wrocławskie środowisko kompozytorów) i jego Unquestioned Answer - wariacja na temat Ivesa na orkiestrę kameralną (1984), z grą intertekstualną w tytule. U Ivesa: The Unanswered Question „Pytanie bez odpowiedzi” (1908), z filozoficzno-kosmologicznym programem), u Krupowicza: „odpowiedź bez pytania”... Ivesowskim brzmieniem naznaczony został także inny utwór Krupowicza - poemat Fin de siècle na orkiestrę (1993). Kompozytorowi bliska w tamtym czasie stała się strategia tworzenia złożonej symfonicznej „nad-faktury”;

- i Eugeniusz Knapik z utworem Tha' Munnot Waste No Time („Nie traćmy czasu”) na trzy (lub dwa) fortepiany i klarnet (1998). „W jakimś sensie Ives został w nas implantowany" - ujawnił reprezentant pokolenia Stalowej Woli w rozmowie z twórcą festiwali „Młodzi Muzycy Młodemu Miastu” - Krzysztofem Drobą. I tłumaczy to w następujący sposób:

Szlachetnością i czystością inwencji - to po pierwsze, a po drugie - oryginalnością niepodobną do czegokolwiek. (...) Odczytuję w tej muzyce rodzaj wo $\ln$ o ści i ${ }^{30}$

- tłumaczy Knapik -

nieznanej mi przedtem, wyzwolenie, nieuwikłanie w cokolwiek. Z tej muzyki e ma nuj e wolno ść, niezależność - od wszystkiego, od przeszłości, od konwencji, od własnego środowiska. Siłą tej wolności kreuje Ives swój świat. Imponuje mi niezwykłym rodzajem inwencji, którą nazwałem tajemniczą, bo jego pomysły powinny wprowadzać chaos, a tymczasem dają scaloną pełnię. (...) Myślę, że podłożem wartości muzyki Ivesa jest jej amerykańskie zakorzenienie. Ives wyrasta wprost ze swojej ziemi, z rodzimej gleby, jest bardzo amerykański. ${ }^{31}$

${ }^{29}$ K. Kiwała, Pokolenie Stalowej Woli. Eugeniusz Knapik, Andrzej Krzanowski, Aleksander Lasoń, Kraków 2019, s. 26.

${ }^{30}$ E. Knapik w rozmowie z K. Drobą - O Ivesie, „Ruch Muzyczny” (2010) 2.

${ }^{31}$ E. Knapik w rozmowie z K. Drobą - O Ivesie, dz. cyt. 
Na pytanie Krzysztofa Droby: „Czy w sztuce wolność nie jest buntem? Przez fakt bycia wolnym mam przeciwko sobie świat. Jeżeli zgadzam się na świat, to się nie buntuję"32 - Knapik odpowiada:

Bycie wolnym nie musi znaczyć, że przeciw czemuś. Chodzi o to, żeby być wolnym nie przez zaprzeczanie, lecz przez wewnętrzny przymus tworzenia now e g o . Ivesowi chodziło o tworzenie. Bunt i niszczenie? - tego u Ivesa nie dostrzegam. Czuję w nim siłę stwarzania nowego świata, nie zaś niszczenia starego. Nie mówił: muszę inaczej pisać, lecz: nie mogę inaczej, bo tak słyszę. To jest otwarcie się ku czemuś, a nie odcięcie od czegoś. Nie wystarczy sam sprzeciw, by stworzyć tak wielkie dzieło, jakie dał nam Ives. W Ivesie widzę nie buntownika, lecz w i e l k i e g o bu d o w ni c z e go - wiernego sobie, swojej wizji świata i muzyki”33.

W refleksji powraca także motyw przeżycia pokoleniowego u kompozytorów związanych integralnie z fenomenem festiwalu „Młodzi Muzycy Młodemu Miastu” w Stalowej Woli. Jak wspomina jego twórca Krzysztof Droba:

naczeną ideą festiwalową było kształcenie i wychowywanie własnej publiczności. Budowanie festiwalu na Ivesie i młodej muzyce polskiej wymagało wykształcenia sobie partnerskiej publiczności. Najchętniej młodej - młodej, bo „młodym” wtedy był w Polsce Ives, bo młodzi byli kompozytorzy i wykonawcy, wreszcie młode było to robotnicze/hutnicze miasto. ${ }^{34}$

Wolność w polskiej kulturze muzycznej w przełomowych dlań latach 70. XX wieku tworzona była zatem na fundamencie idei głoszonych i wyrażanych w dźwiękach przez twórcę Sonaty Concord. Ksiądz Józef Tischner zauważył, iż: „Wolność spełnia się wtedy, gdy kieruje się na zewnątrz siebie samej, ku jakiejś wartości, jakiemuś dobru, gdy je wybiera, urzeczywistnia" ${ }^{35}$. Charles Ives nie tylko umocnił status kompozytora jako artysty wolnego od nakazów formy czy popadnięcia pod władzę stylu, ale pokierował myśl twórczą w stronę tego, co wewnętrzne, substancjalne, duchowe. Bronił tym samym wartości, z których współczesna mu cywilizacja i kultura chciała odrzeć człowieka, pozbawiając go możliwości i umiejętności metafizycznej percepcji świata.

I w konkluzji jeszcze raz przytoczmy poetycki passus z wiersza Whitmana: Opiewam własne ja...

${ }^{32}$ E. Knapik w rozmowie z K. Drobą - O Ivesie, dz. cyt.

${ }^{33}$ E. Knapik w rozmowie z K. Drobą - O Ivesie, dz. cyt.

${ }^{34}$ Krzysztof Droba, Przybliżanie muzyki: Ives, nowy romantyzm i wychowanie estetyczne, „Klucz” (2011) 10.

${ }^{35}$ J. Tischner, Myślenie według wartości, Kraków 1981, s. 200. 
I głoszę zarazem słowo Demokracja... Opiewam Męskość i Kobiecość, Pasjonujący ogrom życia, jego tętno i siłę, Radosną, stworzoną dla wolnych działań pod boskim prawem. Opiewam nowoczesnego człowieka. ${ }^{36}$

\section{Abstract \\ Charles Edward Ives. American singing of freedom}

Charles E. Ives (1874-1954), an American composer - wanted to preach in music and music - freedom and truth. The essence of the composer's outlook on the world is included in his Essays Before a Sonata, which can be interpreted as a unique composer's treaty - the only one of its kind. Ives believed that music was an internally dialectic set of values, composed of two subsets - a higher subset of substance, and a lower subset of style or manner, a manner of expression. He wrote: "Why can't a musical thought be presented as it is born - perchance 'a bastard of the slums', or a 'daughter of a bishop"'. Ives recalls an important thought by Ralph Emerson, the leading figure of American transcendentalism, and his spiritual mentor: "What you are talks so loud, that I cannot hear what you say?" The generation of Stalowa Wola - „new humanists” or „new romantics” - entered the axiological space marked by Ives's thought: Eugeniusz Knapik (1951), Andrzej Krzanowski (1951-1990) and Aleksander Lasoń. They came back to what - after Mikhail Bakhtin and Roger Scruton - I call emotional memory; they were returning through the reception of the views of Ives and his concept of music as a set of values.

Keywords: Charles E. Ives, music as a value, Polish music of the second half of the twentieth century, The Stalowa Wola Generation

${ }^{36}$ W. Whitman, Opiewam własne ja, tłum. A. Międzyrzecki w: ...opiewam nowoczesnego człowieka. Antologia poezji amerykańskiej, wybór i oprac. J. Hartwig i A. Międzyrzecki, Warszawa 1992, s. 4-5. 